\title{
Influence of overweight on functional capacity of physically active older women
}

\section{Influência do sobrepeso na capacidade funcional de mulheres idosas fisicamente ativas}

\author{
Akeline Santos de Almeida ${ }^{1,2}$ \\ (i) https://orcid.org/0000-0001-5364-0835 \\ Patrícia Almeida Fontes ${ }^{1,3}$ \\ (D) https://orcid.org/0000-0002-3107-8404 \\ Jamille Mendonça Reinaldo ${ }^{1}$ \\ (D) https://orcid.org/0000-0001-7104-8317 \\ Maria de Lourdes Feitosa Neta \\ (D) https://orcid.org/0000-0003-4059-2023 \\ Ricardo Aurélio Carvalho Sampaio $0^{1,4}$ \\ (D) https://orcid.org/0000-0002-0005-1145 \\ Roberto Jerônimo dos Santos Silva' \\ (D) https://orcid.org/0000-0002-4578-7666 \\ Rogério Brandão Wichi ${ }^{1}$ \\ (D) https://orcid.org/0000-0001-9678-5858
}

Abstract - Aging comprises a dynamic and progressive process, characterized by physiological and functional changes. Among these changes, increase in body fat is considered relevant, since it can leads to impaired physical fitness and augmented cardiometabolic risks. Considering this, the objective of this study was to evaluate the influence of overweight on functional capacity of physically active older women. A field survey was performed with 24 older women who practiced physical exercise. Participants were submitted to anamnesis, anthropometric measures (i.e., body mass and height); the Senior Fitness test; sit and reach flexibility test; and handgrip strength test. Pearson's correlation test and multivariate logistic regression were used to verify the association between overweight and functional capacity. It was observed that hip flexibility $(\mathrm{R}=-0.494, \mathrm{p}=0.014)$ and flexibility of the lower limbs (i.e., sit and reach test) showed negative correlation with the body mass index $(\mathrm{R}=-0.446, \mathrm{p}=0.02)$; and after the multivariate logistic regression, negative correlation of lower limbs flexibility $(B=-0,035, p=0,014)$ and the body mass index was observed. Thus, higher the body mass index among participants, lower hip flexibility they presented.

Key words: Elderly; Overweight; Physical fitness.

Resumo - O envelhecimento compreende um processo dinâmico e progressivo. Caracteriza-se por alteraçôes fisiológicas e funcionais, sendo a modificação na composição corporal com o acréscimo de gordura corpórea considerada relevante, podendo ocasionar comprometimento da aptidão física e alteraçôes cardiometabólicas. O objetivo deste estudo foi avaliar a influência do sobrepeso na capacidade funcional em idosas praticantes de exercício físico. Foi realizada uma pesquisa de campo correlacional com 24 idosas praticantes de exercício físico. Todas as idosas foram submetidas a anamnese, analise antropométrica com avaliação da massa corporal e estatura, capacidade funcional com a bateria de testes de Rikli e Jones (Sênior Fitness test), flexibilidade com o banco de Wells e força de prensão manual com o teste de preensão manual. Utilizou-se o teste de correlação de Pearson e a regressão logistica multivariada pelo método Stepwise para verificar a associação entre sobrepeso e capacidade funcional. Observou-se que a flexibilidade de Quadril $(R=-0,494, p=0,014)$ e a flexibilidade dos membros inferiores pelo banco de Wells $(R=-0,446, p=0,02)$ apresentaram forte correlação negativa com o indice de massa corporal (IMC). Após a regressão logistica multivariada, percebeu-se uma forte correlação negativa com a flexibilidade do quadril $(B=-0,035, p=0,014)$. Assim, a flexibilidade do quadril entre as idosas ativas com sobrepeso reduziu com o aumento do IMC.

Palavras-chave: Aptidão física; Idoso; Sobrepeso.
1 Federal University of Sergipe. Department of Physical Education. São Cristóvão, SE. Brazil.

2 Federal University of Sergipe. Physiotherapy Department. São Cristóvão, SE. Brazil.

3 Tiradentes University. Physiotherapy Department. Aracaju, SE. Brazil

4 University of Campinas. School of Physical Education, Applied Kinesiology Laboratory. Campinas, SP. Brazil.

Received: 25 September 2019 Accepted: 08 January 2020

How to cite this article Almeida AS, Fontes PA, Reinaldo JM, Feitosa Neta ML, Sampaio RAC, Silva RJS, Wichi RB. Influence of overweight on functional capacity of physically active older women. Rev Bras Cineantropom Desempenho Hum 2020, 22:e67000. DOI: http://dx.doi.org/10.1590/19800037.2020v22e67000

Copyright: This work is licensed under a Creative Commons Attribution 4.0 International License. 


\section{INTRODUCTION}

Aging is a dynamic and progressive process, characterized by both physiological and functional changes - including psychological and cognitive aspects, affecting various systems of our body ${ }^{1,2}$.

Surveys conducted in Brazil lead us to believe that population aging occur faster in developing countries. The last Brazilian Census, held in 2010, for example, showed that aging of population is at an accelerated pace in comparison to Europe ${ }^{3}$. In addition, life expectancy in Brazil is constantly rising, especially due to several advances of science and studies about healthy aging. In this sense, there are multiple public health problems that raise concern, such as physical, psychosocial and economic burdens, caused by an unplanned population aging ${ }^{4,5}$.

Aging causes several biological changes; one of these occurs in body composition, causing increase of body fat and attenuation of muscle mass. In older adults there is a strong tendency towards functional disabilities, which may be directly associated to the amount of adipose tissue in the body, thus limiting functional and cardiorespiratory capacity ${ }^{6}$.

The deficit in motor performance, muscle mass and strength due to physiological aging process is defined as sarcopenia. When these changes are also associated with excess in body fat, it is called sarcopenic obesity. Both conditions are characterized by reduced functional capacity of older adults, limiting them in performing daily life activities (ADL's) and inducing risk factors for cardiometabolic diseases, falls and the frailty syndrome ${ }^{7}$.

Specifically regarding obesity, it is defined as a multifactorial disease (International Classification of Diseases-10 [ICD-10]: E65-E68), composed by physiological, psychological, environmental and cultural factors ${ }^{8}$. Overweight is a global public health concern, a risk factor for cardiovascular disease, and is more common among urban and older people, so prevention and early diagnosis are important for reducing morbidity and mortality 9

Visceral fat accumulation is higher in women after menopause, since they present a higher concentration of fat in abdominal area (i.e., android body type). Men reaches peak of weight at 65 years old and from this phase there is weight reduction; while women reach the peak at 75 years old. Obesity impacts negatively older adults' quality of life, impairing various aspects of functional capacity as well ${ }^{10}$.

The decline in functional capacity increases with age and efforts should be directed to prevent physical dependence, delaying them as much as possible. Then, older people can live longer and with better quality of life ${ }^{11}$. Regular physical exercise and an active lifestyle can improve older adults' mobility, flexibility, motor coordination, muscle strength and cardiorespiratory fitness, as well as preventing several diseases. Therefore, the objective of this study was to evaluate the influence of overweight on functional capacity of physically active older women ${ }^{12}$. 


\section{METHODS}

\section{Study sample}

The sample was selected by convenience. The study included older women who practiced physical exercise twice a week, lasting 50 minutes per session for at least six months at the Tiradentes University Center for Education and Health and had autonomy to perform the test battery. Those with signs of severe orthostatic hypotension, uncorrected visual deficit, associated neurological disease, orthopedic and/or limiting cardiologic changes were excluded.

The study was a correlational field research and had the participation of 24 older women. The research was approved by the Research Ethics Committee of the Federal University of Sergipe, under protocol CAAE \#37891914.9.0000.5546. All participants signed an Informed Consent Form prior participation, according to the National Health Council Resolution 466/12 and the Declaration of Helsinki.

\section{Measurements}

All participants initially underwent an anamnesis about their general health. For anthropometric characterization, body mass was verified using an electronic scale with $0.1 \mathrm{~kg}$ scale, and height using a $0.1 \mathrm{~cm}$ scale stadiometer. To estimate the body mass index (BMI) was used the following formula: body mass / height squared. The cutoff point used for BMI was that proposed by Lipschitz ${ }^{13}$.

Prior to the tests, the researchers adjusted the devices and instructed participants about body positioning in each test. All volunteers wore light clothes (i.e., sportswear) and were motivated to give their best effort during the tests.

To evaluate flexibility, the Wells bench was used to verify lumbar spine and hamstring muscles flexibility (sit and reach). In this test, the volunteers were positioned sitting on a mat with their feet in full contact with the anterior face of the bench and the lower limbs with knee extension and flexed hips. After correct positioning, participants were instructed to move the bench scale forward as much as they could, in trunk flexion. The value obtained for each trial was expressed in centimeters $(\mathrm{cm})$ and was immediately noted by the evaluator. Three attempts were performed and the highest score was recorded for analysis ${ }^{14}$.

Assessment of functional capacity related to daily activities was performed by the Senior Fitness Test battery proposed by Rikli and Jones ${ }^{15}$. This battery consists of six tests that are described below:

a) Chair sit and reach: aimed to assess the flexibility of lower limbs and lower back. The participant sat on the edge of a chair with one knee extended as far as possible and ankle in a neutral position $\left(90^{\circ}\right)$. Then, the subject slowly flexed her trunk with arms extended and hands overlapping. The opposite knee was flexed at 90 degrees. Considering the 
extended knee, the end of the hallux corresponded to the start point. If subject failed to reach this point, the result was considered negative (distance remaining to the hallux) and, overcoming it, the result was positive (distance beyond the hallux). Two attempts were made and the average score was used.

b) Back scratch: the purpose was to assess the flexibility of upper limbs. Standing, the participant put one hand on her back, with the dorsal surface of hand touching her back, preferably near between scapulae. The other arm was placed over the shoulder with the palm of the hand facing the back, and fingers extended. Participant tried to get her hands as close as possible. After explanation, each participant made two attempts and, as a result, the average score was selected. The distance between the middle fingers was measured in $\mathrm{cm}$. A negative score was given when the fingers of both hands could not touch and a positive score when the fingers overlapped.

c) Up-and-go: had the proposal to evaluate agility and dynamic balance. The participant started the test sitting on a chair, hands on thighs and feet flat on the floor. At the evaluator's signal, the participant got up and walked as quickly as possible without running around a cone at a distance of $2.44 \mathrm{~m}$ and returned to the starting position. The timer was started from the evaluator's signal and, stopped, when the participant sat fully in the chair. After explanation, an attempt was made to familiarization and soon after, two attempts were made. We used the best score (time in seconds).

d) 30-s chair stand: aimed to assess lower limb strength. The test began with the participant sitting on a chair and feet flat on the floor. At the evaluator's signal, the participant got up and returned to the starting position. The participant was encouraged to complete as many repetitions as possible within 30 seconds. Before starting test, the evaluator showed the exercise and the participant performed three repetitions to familiarization.

e) Arm curl: intended to assess upper limb strength. The participant started sitting with her back against the chair, elbows in full extension. Then, performed as many as possible elbow flexions and extensions (i.e., concentric and eccentric phases of biceps brachii, brachialis and brachioradialis) in 30 seconds using the dominant limb (load: 5 pounds, approximately $2.3 \mathrm{~kg}$ ). After demonstrating the test, the participant performed three repetitions to familiarization of the task, starting the test afterwards.

f) 6-minute walk: aimed to assess cardiorespiratory resistance. The test considered the distance achieved within 6 minutes, and subjects had to walk as fast as possible. The rectangular course had a total distance of $45.72 \mathrm{~m}$ and was marked by cones every $4.57 \mathrm{~m}$. The participant was warned at 4 and 5 minutes. At the end of time (i.e., 6 minutes), the participant stopped at her position, and then the distance covered was measured. 
To analyze maximum isometric strength, the handgrip strength test was used. The subject remained seated, with the shoulder slightly adducted, the elbow flexed at $90^{\circ}$, the forearm in neutral position and, finally, the position of the wrist ranged from $0^{\circ}$ to $30^{\circ}$ in extension. Three attempts were performed by both hands and the average value was used ${ }^{16}$.

\section{Statistical analysis}

Data were analyzed using the Statistical Package for the Social Sciences (SPSS), version 22.0 (IBM Inc., Chicago, IL, USA). Descriptive analysis was presented as mean and standard deviation (SD). Pearson's correlation test was used to verify the association between obesity and functional capacity, since the Shapiro Wilk test showed normal distribution of the data. Correlation was classified as perfect $(r=1)$, strong $(1>r>0.75)$, moderate $(0.75>r>0.5)$, weak $(0.5>r>0)$ and nonexistent $(r=0)$. Multivariate analysis was performed by multiple linear regression- stepwise method, only for the variables that presented coefficient of correlation higher than 0.40 with the outcome. The level of significance was set at $5 \%$.

\section{RESULTS}

Table 1 shows means, standard deviations and confidence interval of the study participants' characteristics.

Table 1. Mean, standard deviation and confidence interval of anthropometrical and physical fitness of the participants.

\begin{tabular}{lccc}
\hline \multirow{2}{*}{ Characteristics } & Mean (SD) & \multicolumn{2}{c}{$\mathrm{Cl}(95 \%)$} \\
\cline { 3 - 4 } & & Lower & Higher \\
\hline Age (years) & $63.71(5.59)$ & 61.35 & 66.07 \\
Body weight (Kg) & $72.3(12.27)$ & 67.12 & 77.48 \\
Height (cm) & $1.52(0.056)$ & 1.49 & 1.54 \\
BMI (Kg/m²) & $31.23(5.29)$ & 28.99 & 33.47 \\
Up-and-go (seg) & $6.69(3.57)$ & 5.19 & 8.20 \\
30-s chair stand (reps) & $18.8(5.9)$ & 16.35 & 21.32 \\
6-min walk (m) & $486.72(64.24)$ & 459.6 & 513.85 \\
Hip flexibility (cm) & $22.95(7.81)$ & 19.66 & 26.25 \\
VO ${ }_{2}$ max (ml/kg/min) & $18.58(1.92)$ & 17.76 & 19.39 \\
Upper limbs flexibility (cm) & $-12.50(10.48)$ & -16.92 & -8.07 \\
Chair sit and reach (cm) & $-3.18(12.64)$ & -8.52 & 2.15 \\
Arm curl (reps) & $34.87(7.96)$ & 31.52 & 38.24 \\
Handgrip strength (Kg) & $26.35(6.53)$ & 23.6 & 29.11 \\
\hline
\end{tabular}

Note. SD: standard deviation; Cl: confidence interval; BMI: body mass index; hip flexibility: sit and reach test; upper limbs flexibility: average of back scratch test (right and left); chair sit and reach: average between right and left sides; arm curl: average between right and left sides; handgrip strength: average between right and left sides.

Table 2 shows results of Pearson's correlation between the BMI and variables of functional capacity. Most variables presented negative correlations. Arm curl and handgrip strength presented a positive but not significant correlation. Weak correlations were found on upper limb 
flexibility and hip flexibility (Table 2).

Hip flexibility, as assessed by the Wells bench, was better correlated with BMI. This suggests that it is more sensitive to assess the influence of obesity on hip flexibility, in relation to the other variables (Table 2).

Table 2. Pearson's correlation between the body mass index and variables regarding functional capacity in active older women

\begin{tabular}{lcc}
\hline \multirow{2}{*}{ Variables } & \multicolumn{2}{c}{ BMI } \\
\cline { 2 - 3 } & $\mathrm{R}$ & $\mathrm{p}$ \\
\hline 6-min walk & -0.345 & 0.09 \\
Hip flexibility & $-0.494^{*}$ & 0.014 \\
Up-and-go & -0.116 & 0.59 \\
30-s chair stand & -0.002 & 0.99 \\
VO max & -0.345 & 0.099 \\
Upper limbs flexibility & $-0.446^{*}$ & 0.029 \\
Chair sit and reach & -0.15 & 0.47 \\
Arm curl & 0.134 & 0.53 \\
Handgrip strength & 0.09 & 0.66 \\
\hline
\end{tabular}

Note. *:p<0,05; R: Pearson's correlation coefficient; BMI: body mass index; hip flexibility: sit and reach test; upper limbs flexibility: back scratch test.

Table 3 shows the results of multiple linear regression. The BMI was inserted as dependent variable and flexibility of the upper limbs and hip as independent variables. It was observed that obesity was associated with poor flexibility of upper limbs and hip. However, upper limbs flexibility was excluded from analysis because it did not meet the minimum mathematical criteria to influence the model, indicating that obesity had a stronger relationship with hip flexibility.

Table 3. Multiple linear regression (Stepwise Method). The body mass index was inserted as dependent variable and variables regarding functional capacity were inserted as independent variables.

\begin{tabular}{lccccc}
\hline & $\mathrm{R}$ & $\mathrm{R}^{2}$ & $\mathrm{~B}$ & Standard error & $\mathrm{p}$ \\
\hline Constant (BMI) & & & 38.92 & 3.042 & $0.00^{\star \star}$ \\
Hip flexibility & 0.494 & 0.244 & -0.335 & 0.126 & $0.014^{*}$ \\
\hline
\end{tabular}

Note. ${ }^{*}: p<0,05 ;{ }^{* *}: p<0,01 ; B M I$ : body mass index; hip flexibility: sit and reach test; $R 2$ : proportion of explanation of the dependent variable by the independent variable; $B$ : represents the expected change in the dependent variable when there is a change in the independent variable - negative signals indicate opposite relationships.

\section{DISCUSSION}

We verified in this study that being obese did not impair the functional capacity of physically active older women. This result suggests that even overweight, the practice of physical exercise ensure the maintenance of functional capacity during aging process.

Scientific evidence has shown that overweight decreases functional performance in older women ${ }^{17-20}$. Vilaça et al. ${ }^{17}$ recruited 77 active older women to compare body composition, muscle strength and mobility-according to the distance covered during the 6-minute walk test. Anthro- 
pometric measures, handgrip strength, lower limb strength, mobility and balance assessments were performed. The authors concluded that body fat negatively influences functional performance, even in active older women. In the study of Pataky et al. ${ }^{18}$, who evaluated the relationship between BMI and functional capacity $(n=36$; participants were older women allocated in three groups according to body mass: 12 in the obese group; 14 in the severe obesity group; and 10 morbidly obese), concluded that there was a decrease in physical fitness as body mass increased. However, when assessed between groups, reduction in functional capacity with increasing BMI was not observed. In addition, Vagetti et al. ${ }^{20}$ also verified the association of BMI with functional capacity levels of older women participating in a physical exercise program. In their study, 1806 older women were assessed by the Senior Fitness Test battery.

The Senior Fitness Test battery, developed and validated in 1999 by Rikli and Jones, evaluates the main physical parameters associated with functional mobility in independent older adults aged 60 to 90 years old ${ }^{15}$. It is a reliable instrument that measures functional performance on a continuous scale; and is used in several scientific studies to evaluate the functional capacity of older people $\mathrm{e}^{15,20-22}$.

In addition to the Senior Fitness Test battery, the Wells Bench and handgrip dynamometer were also used to assess hip flexibility ${ }^{14}$ and measure handgrip strength ${ }^{23}$, respectively. Such instruments are easy to administer and have low operational cost, recommended for functional capacity assessment and used in several studies s $^{14,17,24,25}$.

There was a significant correlation between BMI and hip and upper limb flexibility, revealing a negative association, even in older women who regularly exercise. However, hip flexibility was influenced by increased body mass, unlike upper limb flexibility. This data corroborates with the study by Sardinha et al. ${ }^{21}$, in which authors verified a significant relationship of overweight and poor physical fitness, except for the flexibility of upper limbs in the older adults who participated in their study. Thus, this result may be explained by the increase in adipose tissue in the abdominal area, representing a risk for developing various cardiometabolic diseases ${ }^{26}$.

It was observed that hip flexibility assessed by the sit and reach test presented the better relationship with the BMI, suggesting that it is more sensitive to evaluate the influence of obesity on hip flexibility. Considering this, the sit and reach test seems to be more reliable to assess hip and lower limb flexibility than the chair sit and reach test as in the Senior Fitness Test protocol.

\section{CONCLUSION}

In conclusion, physically active overweight older women did not present poor levels of total functional capacity, but tend to present lower flexibility of the hip and upper limbs. The practice of physical exercises twice a week may explain the maintenance of their functional capacity. Therefore, we 
suggest that the practice of physical exercise should be encouraged and incorporated to older women's routine to maintain their functional capacity.

\section{COMPLIANCE WITH ETHICAL STANDARDS}

\section{Funding}

This research did not receive any specific grant from funding agencies in the public, commercial, or not-for-profit sectors. This study was funded by the authors.

\section{Ethical approval}

Ethical approval was obtained from the local Human Research Ethics Committee - Federal University of Sergipe, and the protocol CAAE (no. \#37891914.9.0000.5546) was written in accordance with the standards set by the Declaration of Helsinki.

\section{Conflict of interest statement}

The authors have no conflict of interests to declare.

\section{Author Contributions}

Conceived and designed the experiments: ASA; RJSS; RBW. Performed the experiments: ASA; PAF; JMR; MLFN. Analyzed the data: ASA; PAF; JMR; MLFN; RJSS. Contributed reagents/materials/analysis tools: RJSS; RBW; PAF; RACS. Wrote the paper: ASA; PAF; JMR; MLFN; RACS.

\section{REFERENCES}

1. Duarte VS, Santos ML, Rodrigues KA. Exercise and osteoarthrosis: a systematic review. Revista Fisioter Mov 2013; 26(1):193-202.

2. Esquenazi D, Silva SB, Guimarães MA. Aspectos fisiopatológicos do envelhecimento humano e quedas em idosos. Rev HUPE 2014; 13(2):11-20.

3. Campos ACV, Ferreira E, Vargas AMD. Perfil do envelhecimento saudável de idosos brasileiros octogenários. Rev Latino-Am Enfermagem 2016; 24(e): 01-11

4. Ferreira OGL, Maciel SCl, Costa SMG, Silva AO. Active aging and its relationship to functional independence. Texto Contexto Enferm 2012; 21(3): 513-8.

5. Souza MS, Raildo SC, Fernandes MH. Population study on the determinants for self-rated health of elderly residents in Community. Rev Cienc Enferm 2016, 22(2): 13-26.

6. Maciel MG. Physical activity and function in elderly. Motriz 2010; 16(04):10241032,

7. Dos Santos VR, Araujo MYC, Cardoso MR. Association of insufficient physical activity with sarcopenia and sarcopenic obesity in individuals aged 50 years or more. Rev Nutr 2017; 30(2):175-184.

8. Falsarella GR, Gasparotto LPR. Envelhecimento e os fenótipos da Composição Corporal. Rev Kairós Gerontol 2014; 17(2), pp. 57-77.

9. Silveira EA, Kac G, Barbosa LS. Prevalência e fatores associados à obesidade em idosos residentes em Pelotas, Rio Grande do Sul, Brasil: classificação da obesidade segundo dois pontos de corte do índice de massa corporal. Cad Saúde Pública 2009;25(7):1569-1577.

10. De Souza WC, Mascarenhas LPG. Exercício físico na promoção da saúde na terceira idade. Saúde Meio Ambient: Rev Interdiscip 2015; 4(1): 55-65. 
11. Dos Santos RR. Obesity in the elderly. Rev Med Minas Gerais 2013; 23(1): 62-71.

12. De CV Freitas, do Socorro ENFS, Moreira KEC, Carneiro SSR. Evaluation of frailty, functional capacity and quality of life of the elderly in geriatric outpatient clinic of a university hospital. Rev Bras Geriatr Gerontol 2016; 19(1):119-128.

13. Lipschitz DA. Screening for nutritional status in the elderly. Primary care 1994; 21(1): 55-67.

14. Wells KF, Dillon EK. The sit and reach: a test of back and leg flexibility. Res Q Exerc Sport 1952;23:115-118.

15. Rikli R, Jones C. Development and validation of a functional fitness test for community residing older adults. J Aging Phys Act 1999; 7(2):129-16.

16. Sallinen J, Stenholm S, Rantanen T, Heliövaara M, Sainio P, Koskinen S. HandGrip Strength Cut-Points to Screen Older Persons at Risk for Mobility Limitation. J Am Geriatr Soc 2010;58(9):1721-6.

17. Vilaça KHC, Alves NMC, Carneiro JAO, Ferriolli E, Lima NKC, Moriguti JC. Body composition, muscle strength and quality of active elderly women according to the distance covered in the 6-minute walk test Braz J Phys Ther 2013;17(3):289-296.

18. Pataky Z, Armand S, Muller-Pinget S, Golay A, Allet L. Effects of Obesity on Functional Capacity. Obesity 2014; 22(1): 56-62

19. Danielewicz AL, Barbosa AR, Duca GF. Nutritional status, physical performance and functional capacity in an elderly population in southern Brazil. Rev Assoc Med Bras 2014; 60(3):242-248.

20. Vagetti GC, Oliveira V, Silva MP, Pacífico AB, Costa TRA, Campos W. Association of body mass index with the functional fitness of elderly women attending a physical activity program. Rev Bras Geriatr Gerontol 2017; 20(2): 216-227.

21. Sardinha LB, Cyrino ES, dos Santos L, Ekelund U, Santos DA. Fitness but not weight status is associated with projected physical independence in older adults. Age (Dordr) 2016, 38(54): 1-12.

22. Elias RGM, Gonçalves ECA, de Moraes ACF, Moreira CF, Fernandes CAM. Aptidão física funcional de idosos praticantes de hidroginástica. Rev Bras Geriatr Gerontol 2012;15(1):79-86.

23. Giampaoli S, Ferruci L, Cecchi F, Noce CL, Poce A, Dima F, et al. Hand-grip strength predicts incident disability in non-disabled older men. Age Ageing 1999; 28(3): 283-8.

24. Ribeiro C, Abad C, Barros, R, Neto T. Nível de flexibilidade obtida pelo teste de sentar e alcançar a partir de estudo na Grande São Paulo. Rev Bras Cineantropom Desempenho Hum 2010;12(6):415-421.

25. Almeida APPV, Veras RP, Doimo LP. Avaliação do equilíbrio estático e dinâmico de idosas praticantes de hidroginástica e ginástica. Rev Bras Cineantropom Desempenho Hum 2010;12(1):55-61.

26. Song X, Jousilahti P, Stehouwer CDA, Söderberg S, Onat A, Laatikainen T, et al. Cardiovascular and all cause mortality in relation to various anthropometric measures of obesity in Europeans. Nutr Metab Cardiovasc Dis 2015;(25):295-304.

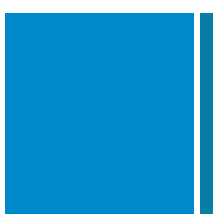

Corresponding author

Akeline Santos de Almeida.

Department of Physical Education or Physiotherapy Department,

Federal University of Sergipe, São Cristóvão, Sergipe, Brazil. Av. Marechal Rondon s/n.

Roza Elze, 49100000.

E-mail: akelinefisioterapeuta@gmail.com 